\title{
Alpha-amylase, antioxidant, and anti-inflammatory activities of Eucheuma denticulatum (N.L. Burman) F.S. Collins and Hervey
}

\begin{abstract}
Eucheuma denticulatum is a red edible seaweed that grows in the East Malaysia coastal region. The objective of this study was to investigate the $\alpha$-amylase, antioxidant and antiinflammatory activities of E. denticulatum ethanol extract and its three fractions (n-hexane, ethyl acetate and acetone). $\alpha$-Amylase activity was assessed by dinitrosalicylic acid (DNS) assay, while the antioxidant property was determined by oxygen radical absorbance capacity (ORAC) analysis. The anti-inflammatory effects of the seaweed samples were evaluated by nitric oxide (NO), interleukin-6 (IL-6), interleukin-1 (IL-1), tumor necrosis factor-alpha (TNF- $\alpha$ ), and monocyte chemoattractant protein-1 (MCP-1) activities on the interferongamma/ lipopolysaccharide (IFN- $\gamma / \mathrm{LPS}$ )-stimulated murine macrophage cell line (RAW 264.7) using Griess reaction and immunoassays, respectively. At $10 \mathrm{mg} \mathrm{mL}-1$, E. denticulatum ethanol extract and three fractions inhibited $\alpha$-amylase activities at variable levels. The highest (67\%) inhibition of $\alpha$-amylase enzyme was by the ethanol crude extract. The three fractions showed inhibition with a mean of $42 \%$. Crude ethanol extracts also exhibited higher antioxidant capacity $(36,400 \pm 23.5$ mol Trolox equivalent (TE) (100 g) -1$)$ when compared to the fractions. Crude extract and fractions (1-100 $\mu \mathrm{g} \mathrm{mL}-1)$, also exhibited anti-inflammatory activity without showing any cytotoxic effect to RAW 264.7 cells. The present study suggests that E. denticulatum has the potential to be a promising source of effective functional metabolite. An extensive research on the edible varieties would contribute to a better understanding of their importance as functional food.
\end{abstract}

Keyword: $\quad \alpha$-Amylase; Anti-inflammatory; Antioxidant; Rhodophyta; Eucheuma denticulatum; Seaweed 